DOI: https://doi.org/10.32838/2523-4803/70-1-9

УДК 330.341 .1

\title{
Мігай Н.Б.
}

кандидат економічних наук,

доцент кафедри економіки та організації виробництва,

Первомайська філія Національного університету

кораблебудування імені адмірала Макарова

\section{Mihai Natalia}

Pervomaisk branch of

Admiral Makarov National University of Shipbuilding

\section{ДЕРЖАВНО-ПРИВАТНЕ ПАРТНЕРСТВО У СФЕРІ ІННОВАЦІЙНОЇ ДІЯЛЬНОСТІ: ЗАКОРДОННИЙ ДОСВІД ТА ВІТЧИЗНЯНІ РЕАЛІї}

\begin{abstract}
У статті визначено важливість державно-приватного партнерства для налагодження дієвих механізмів розвитку інноваційної діяльності та економічного зростання країни. На основі узагальнення нормативно-правових та наукових джерел уточнено поняття державно-приватного партнерства в інноваційній сфері та його переваги для держави і приватного (інноваційного) бізнесу. Вказано напрями взаємодії держсави та приватного (інноваційного) бізнесу на різних стадіях розвитку: "посівній», стартапа, раннього зростання та розширення. Вивчено зарубіжний досвід державно-приватного партнерства. Проаналізовано стан державно-приватного партнерства в Украӥні, визначено чинники, щзо стримують його розвиток. Окреслено варіанти державно-приватного партнерства 6 інновачійній сфері України, можливості їх реалізації та очікувані результати.

Ключові слова: державно-приватне партнерство, інноваційна сфера, приватний бізнес, інноваиійний бізнес, інноваційна діяльність, інвестииії, комеричіалізація інноваційної продукиії.
\end{abstract}

Постановка проблеми. У сучасних умовах залежності економічного зростання від рівня інноваційності економічних процесів поєднання державного регулювання інноваційної діяльності з ринковим є зумовленим і актуальним. В Україні за роки незалежності створене правове поле для здійснення інвестицій та налагодження державно-приватного партнерства. Вітчизняним законодавством визначено гарантії діяльності для інвесторів, а також організаційно-економічні основи реалізації державно-приватного партнерства. Проте події останніх років створили несприятливі передумови формування та розвитку вітчизняної інноваційної системи країни, призвели до складної економічної ситуації, зниження інноваційної активності господарюючих суб'єктів. Так, якщо в 2016 р. інноваційно активними були 18,9\% (834 підприємства) від загальної кількості промислових підприємств, то вже у 2018 р. лише 16,4\% (777 підприємств) [7, с. 65]. Окрім того, згідно $з$ дослідженнями вітчизняних науковців, в Україні менше $10 \%$ від загального обсягу інвестицій спрямовується на інновації, тоді як за кордоном ця цифра становить 50-60\% [3]. Частка іноземних інвестицій в інновації, що була залучена у 2018 р., становить лише $0,25 \%$ від загальної суми прямих іноземних інвестицій (2,4 млрд дол. США), що зайшли в Україну. Усе зазначене вище свідчить про необхідність посилення взаємодії держави та приватного сектору для налагодження дієвих механізмів розвитку інноваційної діяльності, забезпечення економічного зростання у довгостроковій перспективі та розбудови національної інноваційної системи.

Аналіз останніх досліджень і публікацій. Проблемі державно-приватного партнерства присвячено праці багатьох вітчизняних та зарубіжних науковців: О. Акіліна, С.М. Даниленко, Т.С. Воронкова, I.А. Косач, Т.М. Кришталь, I.С. Нейкова, С.В. Сімака, В.О. Стойка, Н.В. Філіппова, М.А. Федченко, Г. Ходжа, Е. Саваса, Е.Х. Кляйна, Г. Тейсмана та ін. Ними визначено поняття державно-приватного партнерства, встановлено його функції, форми, моделі, важелі взаємодії сторін реалізації договорів. Водночас у зазначених працях вплив державного партнерства на сферу інноваційної діяльності 3 урахуванням закордонного та вітчизняного досвіду вивчено недостатньо і потребує подальшого дослідження.

Формулювання цілей статті. Метою статті $є$ уточнення визначення державно-приватного партнерства в інноваційній сфері, дослідження вітчизняного та закордонного досвіду державно-приватного партнерства у сфері інноваційної діяльності та формування пропозицій щодо створення дієвих механізмів його розвитку.

Виклад основного матеріалу. Здійснення стратегічних проєктів, спрямованих на інноваційний розвиток та забезпечення конкурентоспроможності регі- 
ону чи країни у цілому, неможливе без поєднання державних та приватних інтересів і засобів. Сьогодні обов'язковою умовою ефективності державно-приватного партнерства $\epsilon$ розуміння його сутності, складників та форм здійснення (табл. 1), а також існування системного підходу до визначення пріоритетів державної політики в інноваційній сфері та державного замовлення на інноваційну продукцію [9].

Можна стверджувати, що державно-приватне партнерство сьогодні є одним із найуживаніших термінів, розглядається в різних площинах: економічній, правовій, соціальній тощо, але системності у його визначенні немає.

Уважаємо, що державно-приватне партнерство в інноваційній сфері - це інституційна, організаційна та фінансова взаємодія органів державної влади, муніципальних органів управління та приватного (інноваційного) бізнесу, спрямована на спільну реалізацію інноваційних проєктів і взаємопідтримку на всіх стадіях інноваційного процесу.

Отже, державно-приватне партнерство в інноваційній сфері вимагає від сторін взаємоузгодженості дій та ефективного виконання функціональних обов'язків у правовій, інституційній, фінансовій, організаційній площинах. Стаючи активним учасником інноваційного процесу, держава виконує функції нормативно-правового регулювання, створення інноваційної інфраструктури, стимулювання приватного бізнесу та підтримки інноваційних підприємств. Приватний бізнес здійснює дослідження та розроблення інноваційних продуктів, участь у фінансуванні, оцінку ринку, забезпечує ефективне управління та підтримку інфраструктури комер- ціалізації інноваційного продукту, доведення його до кінцевого споживача.

За такої взаємодії приватний бізнес отримує певні переваги, зокрема захист від ризиків, адже державний сектор більш захищений від кон'юнктурних коливань ринку; можливість реалізовувати великі інфраструктурні проєкти, що вимагають значних фінансових вливань; відбір пріоритетів та формування дослідницького потенціалу; максимізація прибутку від комерціалізації інноваційних продуктів.

Інноваційний бізнес у своєму розвитку проходить декілька стадій, які дещо відрізняються за організаційними, маркетинговими, управлінськими аспектами, а також за використанням джерел і форм фінансування:

- «посівна» - здійснюється на стадії формування фірми, коли наявна лише бізнес-ідея чи бізнес-проєкт, здійснюються маркетингові дослідження, НДДКР, формується команда;

- стартап - фірма вже створена, має дослідні зразки продукції (можливо, запатентовані) та намагається організувати виробництво з виходом продукції на ринок інновацій;

- раннє зростання - стадія, на якій суб'єкт інноваційного бізнесу виробляє продукцію, реалізує іiі на ринку, хоча не має достатніх прибутків;

- розширення - фірма займає на ринку визначені позиції, стає прибутковою, але їй потрібні фінансові ресурси для розширення виробництва і збуту, здійснення додаткових маркетингових досліджень тощо [5, с. 214].

Кожна зі стадій характеризується певним спектром напрямів взаємодії держави та бізнесу (табл. 2).

Таблиця 1

Аналіз тлумачення поняття «державно-приватне партнерство»

\begin{tabular}{|c|c|}
\hline Джерело & Визначення поняття \\
\hline $\begin{array}{l}\text { Закон України } \\
\text { «Про державно-приватне } \\
\text { партнерство» [4] }\end{array}$ & $\begin{array}{l}\text { Співробітництво між державою Україна, Автономною Республікою Крим, територіальними } \\
\text { громадами в особі відповідних державних органів та органів місцевого самоврядування } \\
\text { (державними партнерами) та юридичними особами, крім державних комунальних підприємств, } \\
\text { або фізичними особами - підприємцями (приватними партнерами), що здійснюється на основі } \\
\text { договору в порядку, встановленому Законом та іншими законодавчими актами, та відповідає } \\
\text { ознакам державно-приватного партнерства, визначеного Законом. }\end{array}$ \\
\hline $\begin{array}{l}\text { T.C. Воронкс } \\
\text { I.В. Воронко }\end{array}$ & $\begin{array}{l}\text { Нові технології розвитку економіки є вагомим чинником інноваційно-інвестиційної безпеки } \\
\text { національної економіки. Активна співпраця всіх суб’єктів, яка активізується на засадах пошуку } \\
\text { спільних напрямів реалізації визначених цілей. Партнерами стають суб'єкти державного } \\
\text { управління і регулювання інноваційного розвитку економіки, продукування нових знань і } \\
\text { інновацій, освіти та підвищення кваліфікації працівників, комерціалізації наукових знань і } \\
\text { інновацій, використання інновацій. }\end{array}$ \\
\hline $\begin{array}{l}\text { I.А. Косач, } \\
\text { М.А. Федченко [12] }\end{array}$ & $\begin{array}{l}\text { Взаємодія держави і приватного сектору в процесі всього інноваційного циклу - від проведення } \\
\text { наукових досліджень і впровадження розробок до виробництва наукомісткої високотехнологічної } \\
\text { продукції. }\end{array}$ \\
\hline$c[14]$ & $\begin{array}{l}\text { Будь-яка угода, в якій державний і приватний сектори об’єднуються для виробництва та надання } \\
\text { товарів і послуг; формальна співпраця між бізнесом, суспільством та місцевими органами влади } \\
3 \text { метою розвитку територій та поліпшення життя населення, у рамках якої традиційні ролі } \\
\text { держави та приватного сектору перерозподіляються. }\end{array}$ \\
\hline В.Г. Варнавс & $\begin{array}{l}\text { Інституційний і організаційний альянс між державою та бізнесом із метою реалізаціїнаціональних } \\
\text { і міжнародних проєктів у галузі промисловості, НДДКР, суспільних послуг. }\end{array}$ \\
\hline М.В. Вілісов [2] & $\begin{array}{l}\text { Правовий механізм узгодження інтересів та забезпечення рівноправ'я держави та бізнесу в рамках } \\
\text { реалізації економічних проєктів, спрямованих на досягнення цілей державного управління. }\end{array}$ \\
\hline Г.М. Розум [10] & $\begin{array}{l}\text { Інституційний та організаційний альянс між державою і бізнесом із метою реалізації суспільно- } \\
\text { значущих проєктів і програм у широкому спектрі галузей промисловості та в інноваційній сфері. }\end{array}$ \\
\hline
\end{tabular}


Таблиця 2

Взаємодія держави та приватного (інноваційного) бізнесу на різних стадіях

\begin{tabular}{|l|l|l|}
\hline \multirow{2}{*}{ Стадія розвитку бізнесу } & \multicolumn{1}{|c|}{ Напрями взаємодії } \\
\cline { 2 - 3 } & \multicolumn{1}{|c|}{ Держава } & \multicolumn{1}{|c|}{ Приватний бізнес } \\
\hline «Посівна» & $\begin{array}{l}\text { Створення механізму взаємодії учасників } \\
\text { інноваційного процесу. Визначення } \\
\text { пріоритетів та координування } \\
\text { фундаментальних досліджень. Стимулювання } \\
\text { інноваційної діяльності. }\end{array}$ & $\begin{array}{l}\text { 3дійснення досліджень. Оцінка можливості } \\
\text { використання результатів інновацій. Передача } \\
\text { знань. }\end{array}$ \\
\hline «Стартап» & $\begin{array}{l}\text { Підтримка інфраструктури передачі знань. } \\
\text { Інституційна та організаційна взаємодія. }\end{array}$ & $\begin{array}{l}\text { Організаційні процедури розроблення } \\
\text { інноваційного продукту. }\end{array}$ \\
\hline Раннє зростання & $\begin{array}{l}\text { Захист від ризиків, поглинання великими } \\
\text { компаніями. Інфраструктурна та фінансова } \\
\text { підтримка. }\end{array}$ & $\begin{array}{l}\text { Створення інноваційного продукту. Забезпечення } \\
\text { виробництва, ринкове освоєння та дифузія } \\
\text { інноваційного продукту. }\end{array}$ \\
\hline Розширення & $\begin{array}{l}\text { Розвиток інфраструктури комерціалізації } \\
\text { інноваційного продукту. }\end{array}$ & $\begin{array}{l}\text { Комерціалізація інноваційного продукту. } \\
\text { Доведення інноваційного продукту до кінцевого } \\
\text { споживача. Визначення економічного ефекту } \\
\text { партнерства. }\end{array}$ \\
\hline
\end{tabular}

Приклад ефективної взаємодії держави та приватного бізнесу в інноваційній сфері демонструють зарубіжні країни, при цьому кожна з них вибрала пріоритетні напрями та глибину взаємодії. Сьогодні існує класифікація країн за мірою впровадження процесів державно-приватного партнерства у національні економічні системи [13].

Першу групу становлять економічно розвинені країни: США, Канада, Японія, Сінгапур, Великобританія, Франція, Німеччина, Ірландія та Італія, в яких найбільше сфер задіяні у реалізації проєктів на основі державно-приватного партнерства.

Пріоритетними напрямами державно-приватного партнерства у Великобританії є сфера освіти, охорона здоров'я, житлове будівництво, оборона, автомобільні дороги, ІТ-інфраструктура та ін. Необхідно зазначити, що Великобританія почала однією 3 перших застосовувати механізми державно-приватного партнерства на національному рівні й сьогодні є лідером із реалізації спільних проєктів.

США реалізує проєкти державно-приватного партнерства у сфері природоохоронної діяльності, забезпечення розвитку сільських територій.

Франція значну кількість проєктів виконує у сферах охорони здоров'я, залізничного транспорту, будівництва автомобільних доріг, систем життєзабезпечення міст. Інструментом підтримки інноваційної діяльності на засадах державно-приватного партнерства у Франції $€$ створення інноваційних кластерів, так званих «полюсів конкурентоспроможності», які об'єднують на визначеній території приватні підприємства, державні дослідницькі та освітні організації.

Ірландія та Італія переважно зосередилися на проєктах державно-приватного партнерства у сферах охорони здоров'я, транспорту та житлово-комунального господарства міст.

У Німеччині найбільша увага приділяється сферам будівництва та реконструкції міської інфраструктури, освіти, оборони та охорони здоров'я. Реалізуються проєкти відновлення занедбаних земель.
До другої групи входять країни із середнім рівнем державно-приватних партнерств (так звані проміжні країни), в яких ці механізми використовуються лише в деяких пріоритетних сферах: Іспанія, Португалія, Нідерланди та деякі інші.

Іспанія найбільшу увагу в розвитку державно-приватного партнерства зосередила на розвитку портів, охороні здоров'я, будівництві доріг та життєзабезпеченні міст.

Нідерланди пріоритетними сферами державноприватного партнерства вибрали освіту, транспортне сполучення (залізничне та автомобільне) та житлово-комунальне господарство. Необхідно зазначити, що більшість проєктів у зазначених сферах знаходиться на стадії розроблення або тільки почали впроваджуватися.

Третя група країн включає у себе країни, де використання державно-приватного партнерства тільки розпочинається: Люксембург, Бельгію, Грецію, Норвегію та деякі інші.

Окремо необхідно відзначити групу країн, які в державно-приватному партнерстві зосередили свою увагу на інноваційній сфері.

Так, Австрія запровадила ще 31998 р. програму Kplus, яка спрямована на створення кооперативних дослідницьких ініціатив між державними установами та приватним бізнесом на довгостроковій основі. Також запущена i працює програма державно-приватного партнерства Kind/Knet, яка забезпечує інфраструктуру та мережі для передачі знань та технологій. Програма Christian Doppler Laboratories, метою якої є виконання фундаментальних досліджень, забезпечення доступу до новітніх знань та здійснення перспективних науково-дослідних та дослідно-конструкторських робіт у довгостроковому періоді.

Австралія запровадила систему стимулювання державно-приватного партнерства в інноваційній сфері, створивши мережу центрів спільних досліджень (Cooperative Research Centres). Їх призначення - забезпечення трансферу знань та комерціалізація інновацій. 
У Словаччині уряд реалізує програму «Податкові пільги для технологічних центрів», пропонує державну допомогу у вигляді податкового кредиту.

Уряд Чехії запустив програму «Інвестиційні стимули для дослідницьких центрів». Серед пільг, які можуть отримати дослідницькі центри: податкові канікули щодо сплати податку на прибуток на період до 10 років; дотації на навчання і перепідготовку працівників у розмірі до $70 \%$ від допустимих витрат на навчання в регіонах із високим рівнем безробіття; грошові субсидії у розмірі до $10 \%$ від обсягу капітальних витрат на дослідницькі центри у разі стратегічних інвестицій.

У Китаї кожен великий науково-дослідницький університет має структуру з трансферу технологій, що фінансується урядом із загальної суми коштів виділених для закладу.

Деякі країни намагаються залучати іноземні інвестиції на проведення науково-дослідних та дослідно-конструкторських робіт на засадах державно-приватного партнерства через проведення масштабних рекламних кампаній (Німеччина, Фінляндія, Австрія тощо).

Так, заохочуючи та стимулюючи інноваційну діяльність, оптимально розподіляючи повноваження, країни забезпечують стійкий економічний розвиток та зайнятість населення. При цьому форми взаємодії держави і приватного бізнесу сьогодні можуть бути досить різноманітними: контракти, оренда, концесія, спільні підприємства, угода про розподіл продукції тощо.

В Україні за роки незалежності вже набутий певний досвід державно-приватного партнерства. Прийнято Закон України «Про державно-приватне партнерство» (2010 р.), затверджено Концепцію розвитку державноприватного партнерства в Україні на 2013-2018 pp. (2013 р.), яка визначила основи державно-приватного партнерства, функції, моделі, його проблеми та особливості здійснення.

У березні 2019 р. почала роботу Агенція з питань державно-приватного партнерства. Ї̈̈ основним завдан- ням визначено здійснення заходів для реалізації в Україні якісних та інвестиційно-привабливих проєктів державно-приватного партнерства у різних сферах економіки [6].

Прийнято Закон України «Про концесію» (жовтень 2019 р.) [8], який розроблено з урахуванням норм та стандартів європейського законодавства, а також дію його статей узгоджено із Законом України «Про державно-приватне партнерство». Усе це має велике значення для розвитку сфери державно-приватного партнерства в Україні.

Згідно $з$ даними Міністерства розвитку економіки, торгівлі та сільського господарства України, кількість укладених договорів державно-приватного партнерства щороку зростає (рис. 1), проте, на жаль, більшість із них не реалізується (рис. 2).

Необхідно зазначити, що серед укладених проєктів державно-приватного партнерства та проєктів, що реалізуються, перевагу мають інфраструктурні проєкти на засадах концесії, згідно з якою приватний інвестор отримує можливість вкладати кошти у розвиток об'єктів інфраструктури, що передані йому в управління, та отримувати частину прибутку від їхньої діяльності.

Зокрема, у 2019 р. найбільше договорів державноприватного партнерства було укладено у сферах водопостачання, будівництва доріг, а також виробництва й транспортування природного газу.

Позитивним у розвитку державно-приватного партнерства у сфері інноваційної діяльності є створення в Україні Державної фінансово-кредитної установи (ДІФКУ), метою якої є залучення інвестицій та створення умов для здійснення інноваційного бізнесу на засадах бізнес-позик, лізингу, консорціумного кредитування, залучення іноземних інвестицій тощо.

Незважаючи на позитивні перетворення і збільшення загальної кількості укладених договорів державно-приватного партнерства, в Україні якісного розвитку в реалізації інноваційних проєктів не відбува-

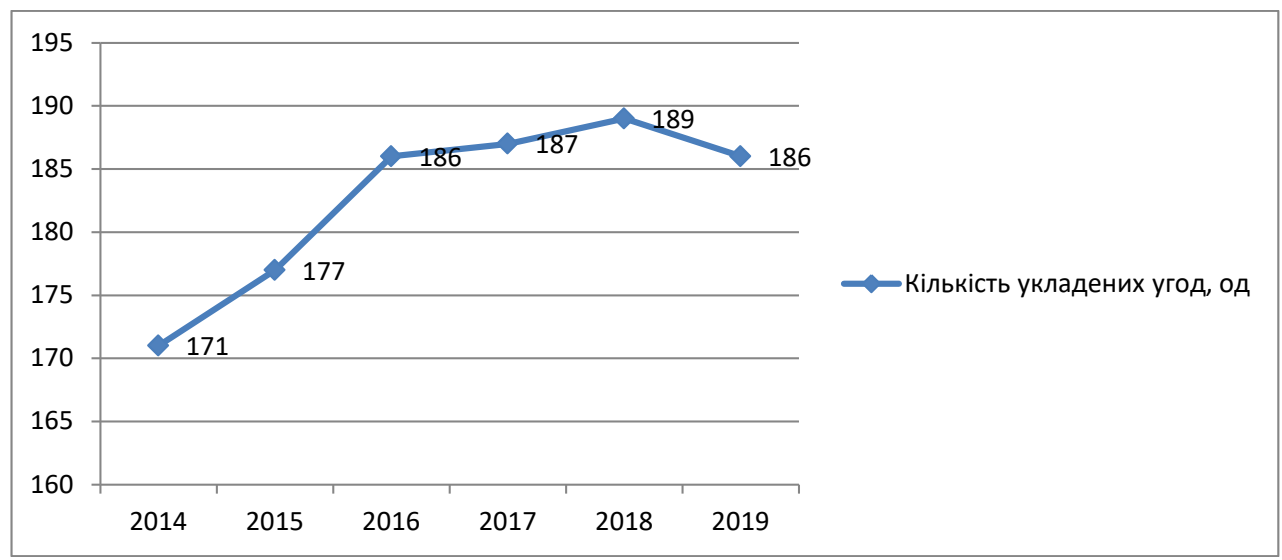

* Дані за 2019 р. на 01.07.2019.

Рис. 1. Динаміка кількості угод державно-приватного партнерства в Украӥні

Джерело: побудовано автором на основі [11] 


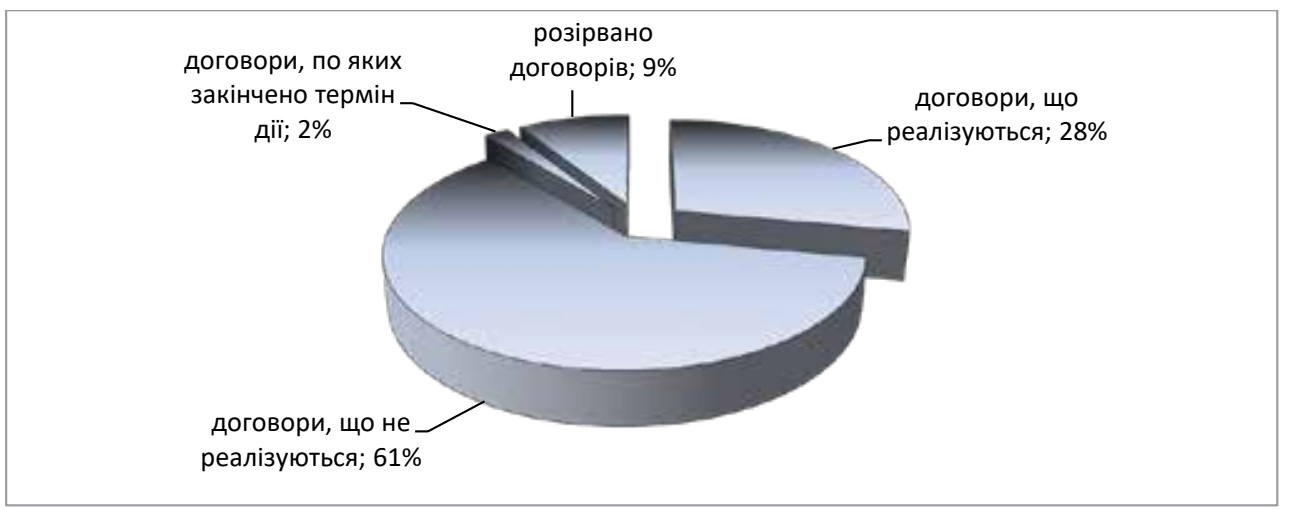

Рис. 2. Стан виконання угод державно-приватного партнерства в Україні на 01.07.2019

Джерело: побудовано автором на основі [11]

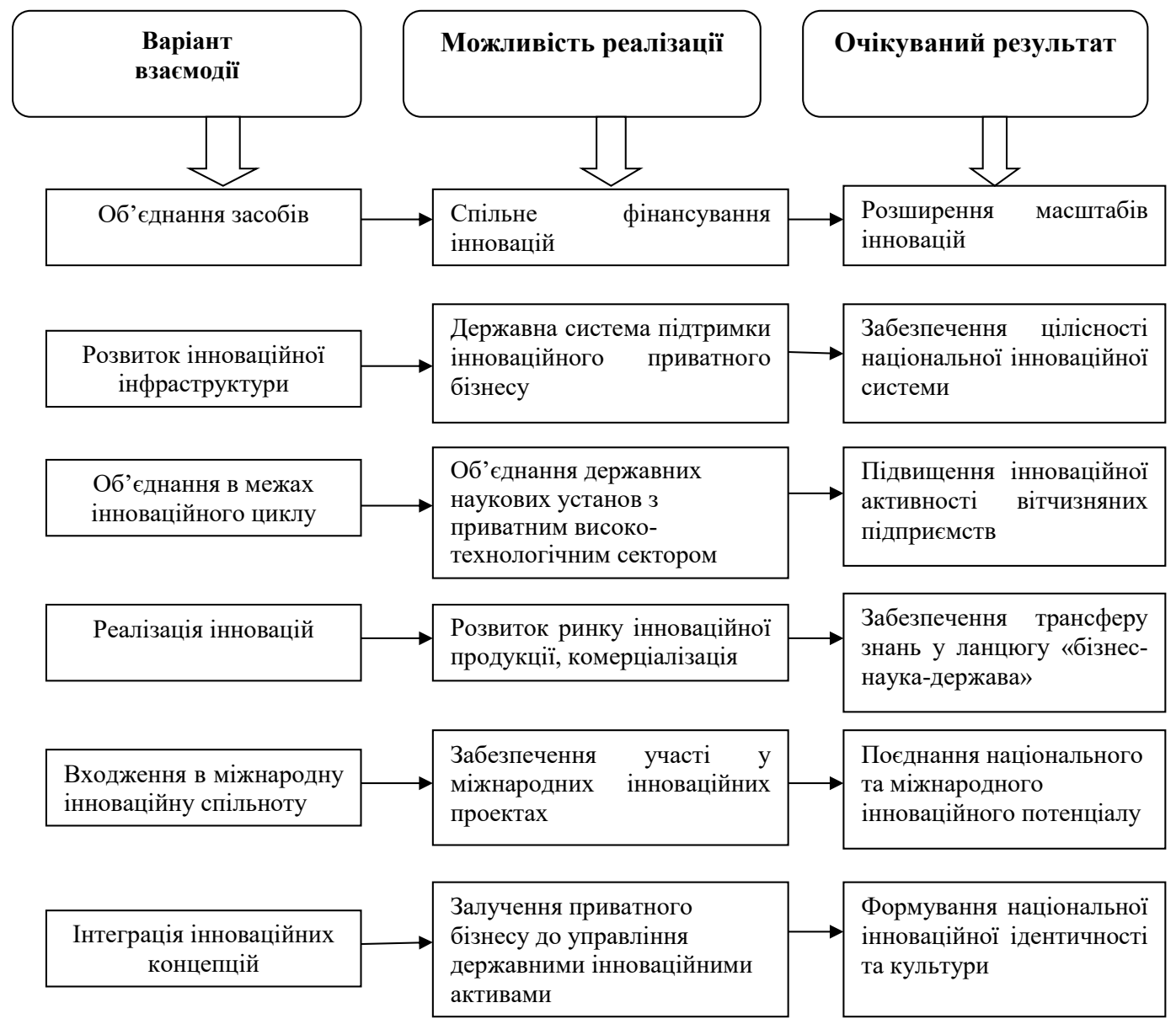

Рис. 3. Варіанти державно-приватного партнерства в інноваційній сфері України

Джерело: складено автором

ється. На разі розвиток державно-приватного партнерства в інноваційній сфері все ще на стадії становлення та підвищеного ризику.

На нашу думку, основними чинниками, що стримують розвиток державно-приватного партнерства у сфері інноваційної діяльності в Україні, є: недостатність досвіду у забезпеченні системної та ефективної взаємодії між державою та приватним (інноваційним) бізнесом; відсутність дієвих стимулів для вітчизняних та закордонних інвесторів, економічна нестабільність і значні ризики втрати вкладених коштів; нерозвиненість інноваційної інфраструктури; відсутність кваліфікованих кадрів, здатних забезпечити механізм реалізації державно-приватного партнерства; неузгодженість різних законодавчих і нормативних актів, що забезпечують правове поле й організаційно-економічні 
умови для здійснення державно-приватного партнерства в інноваційній сфері.

Під час налагодження державно-приватного партнерства в інноваційній сфері держава має виступати як безпосередній суб'єкт інноваційної діяльності, підтримуючи державний високотехнологічний сектор та забезпечуючи перспективні напрями взаємодії 3 приватним інноваційним бізнесом. Держава має збалансувати інтереси приватного бізнесу із загальнонаціональними пріоритетами, сформувати сприятливий інвестиційний клімат у країні, створити умови для розвитку стартапів.

Зарубіжний досвід державно-приватного партнерства у сфері інноваційної діяльності свідчить про наяв- ність різних варіантів його реалізації. На рис. 3 згруповано варіанти державно-приватного партнерства, які, виходячи із зарубіжного досвіду, доцільно імплементувати у вітчизняну практику стимулювання інноваційної діяльності.

Висновки. Для України необхідна модель розвитку державно-приватного партнерства в інноваційній сфері, яка б забезпечувала нерозривність ланцюга «бізнес - наука - держава» та дала б змогу сформувати національну інноваційну систему. Інституційне забезпечення процесів державно-приватного партнерства створить умови для реального залучення приватного бізнесу у сферу інноваційної діяльності та сформує конкурентні переваги країни у довгостроковій перспективі.

\section{Список літератури:}

1. Варнавский В.Г. Партнерство государства и частного сектора: формы, проекты, риски / РАН ; Институт мировой экономики и международных отношений. Москва : Наука, 2005. 315 с.

2. Вилисов М.В. Государственно-частное партнерство: политико-правовой аспект. Власть. 2006. № 7. URL : http://www.rusrand.ru/public/public_7.html (дата звернення: 11.01.2020).

3. Воронкова Т.С., Воронков І.В. Державно-приватне партнерство як інструмент активізації інноваційної діяльності. Науково-технічна інформачія. 2014. № 2. С. 28-36.

4. Про державно-приватне партнерство : Закон України від 1 липня 2010 р. № 2404-VI / Верховна Рада України. URL : https://zakon.rada.gov.ua/laws/show/2404-17 (дата звернення: 21.01.2020).

5. Мігай Н.Б. Джерела фінансування інноваційного бізнесу України в контексті закордонного досвіду. Development of modern science: the experience of European countries and prospects for Ukraine : monograph / edited by authors. 1 st ed. Riga, Latvia : Baltija Publishing, 2019. C. 210-232.

6. Міжнародна фінансова корпорація консультуватиме Мінекономрозвитку щодо Агенції з питань підтримки державно-приватного партнерства. URL : http://www.me.gov.ua/News/Detail?lang=uk-UA\&id=4cb024e1-a562-466f-b953-4 51d0d626729\&title=MizhnarodnaFinansovaKorporatsiiaKonsultuvatimeMinekonomrozvitkuSchodoAgentsiiZPitanPidtrim kiDerzhavnoprivatnogoPartnerstva (дата звернення: 21.01.2020).

7. Наукова та інноваційна діяльність України : статистичний збірник / Державна служба статистики України. Київ, 2019. С. 65.

8. Новий закон про концесію: які зміни чекають на ДПП. URL : https://legalaid.ua/ua/article/novyj-zakon-prokonczesiyu-yaki-zminy-chekayut-na-dpp/ (дата звернення: 20.01.2020).

9. Про схвалення Концепції реформування державної політики в інноваційній сфері : Розпорядження КМУ від 10 вересня 2012 р. № 691-p. URL : https://zakon.rada.gov.ua/laws/show/691-2012-p (дата звернення: 14.01.2020).

10. Розум Г.М. Державно-приватне партнерство як ефективний інструмент реалізації інноваційної політики регіонів. Інвестииї̈: практика та досвід. 2017. № 20. С. 90-92.

11. Стан здійснення ДПП в Україні. URL : http://www.me.gov.ua (дата звернення: 19.01.2020).

12. Федченко М.А., Косач I.А. Державно-приватне партнерство в інноваційній сфері: український та зарубіжний досвід. Вісник Чернігівського державного технологічного університету. 2013. № 2(66). С. 365-371.

13. Renda A., Schrefler L. Public Private Partnerships: National Experiences in the European Union. Briefing note №IP/A/IMCO/SC/2005-160 governed by the provisions of Framework Service Contract IP/A/IMCO/FWC/2005-33. URL : $\mathrm{http}: / /$ euro2005.inform/news/11/h7273 (дата звернення: 14.01.2020).

14. Savas E.S. Privatization and Public Private Partnerships. Fordham Urban Law Journal. 2000. Volume 28. Issue 5. Article 8. P. 1730-1737. URL : http://ir.lawnet.fordham.edu (дата звернення: 14.01.2020).

\section{References:}

1. Varnavskyi V.H. (2005) Partnerstvo hosudarstva y chastnoho sektora: formy, proekty, risky [Public-private partnership: Forms, Projects, Risks] / RAN; Ynstytut myrovoi ekonomyky y mezhdunarodnykh otnoshenyi. Moskva: Science, p. 315. (In Russian)

2. Vylysov M.V. (2006) Hosudarstvenno-chastnoe partnerstvo: polytyko-pravovoi aspect. [Public-private partnership: political and legal aspects]. Vlast. no 7. Available at: http://www.rusrand.ru/public/public_7.html (accessed: 11.01.2020)

3. Voronkova T.Ye., Voronkov I.V. (2014) Derzhavno-pryvatne partnerstvo yak instrument aktyvizatsii innovatsiinoi diialnosti. [Public-private partnership as tool for stimulating innovation]. Scientific and technical information. no 2. pp. 28-36.

4. Про державно-приватне партнерство : Закон України від 1 липня 2010 р. № 2404-VI [On Public-Private Partnership: Law of Ukraine of July 1, 2010 No. 2404-VI]. Verkhovna Rada Ukrainy. Available at: https://zakon.rada.gov.ua/ laws/show/2404-17 (accessed: 21.01. 2020) 
5. Mihai N.B. (2019) Dzherela finansuvannia innovatsiinoho biznesu Ukrainy v konteksti zakordonnoho dosvidu.[Sources of financing of innovative business in Ukraine in the context of foreign experience]. Development of modern science: the experience of European countries and prospects for Ukraine. Monograph / edited by authors. 1st ed. Riga, Latvia : "Baltija Publishing”. p. 210-232.

6. Mizhnarodna finansova korporatsiia konsultuvatyme Minekonomrozvytku shchodo Ahentsii z pytan pidtrymky derzhavno-pryvatnoho partnerstva. [The International Finance Corporation will advise the Ministry of Economic Development on the Agency for public-partnership support]. Available at: http://www.me.gov.ua/News/Detail?lang=uk-UA\&id=4cb024e1a562-466f-b953-451d0d626729\&title=MizhnarodnaFinansovaKorporatsiiaKonsultuvatimeMinekonomrozvitkuSchodoAge ntsiiZPitanPidtrimkiDerzhavnoprivatnogoPartnerstva (accessed: 21.01. 2020)

7. Naukova ta innovatsiina diialnist Ukrainy. (2019). [Scientific and innovative activity of Ukraine]. Statistical collection. State statistics service of Ukraine. pp. 65.

8. Novyi zakon pro kontsesiiu: yaki zminy chekaiut na DPP. [The new concession law: what changes are waiting PPP]. Available at: https://legalaid.ua/ua/article/novyj-zakon-pro-konczesiyu-yaki-zminy-chekayut-na-dpp/ (accessed: 20.01. 2020)

9. Pro skhvalennia Kontseptsii reformuvannia derzhavnoi polityky v innovatsiinii sferi [ On approval of the Concept of reforming the state policy in the innovation sphere]: Rozporiadzhennia KMU vid 10 veresnia 2012 r. no 691-p. Available at: https://zakon.rada.gov.ua/laws/show/691-2012-p (accessed: 14.01.2020)

10. Rozum H.M. (2017). Derzhavno-pryvatne partnerstvo yak efektyvnyi instrument realizatsii innovatsiinoi polityky rehioniv. [Conceptual approaches for the formation of mechanisms of public administration innovative development of regions] Investment: practice and experience. no 20. pp.90-92.

11. Stan zdiisnennia DPP v Ukraini. [State of PPP implementation in Ukraine] Available at: http://www.me.gov.ua (accessed: 19.01.2020).

12. Fedchenko M.A., Kosach I.A. (2013) Derzhavno-pryvatne partnerstvo v innovatsiinii sferi: ukrainskyi ta zarubizhnyi dosvid. [The public-private partnership in the sphere of innovations: Ukrainian and abroad experience]. Bulletin of Chernigiv State Technological University. no 2. vol. 66. pp. 365-371.

13. Renda A. Schrefler L. Public Private Partnerships: National Experiences in the European Union. Briefing note №IP/A/ IMCO/SC/2005-160 governed by the provisions of Framework Service Contract IP/A/IMCO/FWC/2005-33. Available at: http://euro2005.inform/news/11/h7273 (accessed: 14.01.2020)

14. Savas E. S. Privatization and Public Private Partnerships. N. Y.: Chatham House. Fordham Urban Law Journal. 2000, vol. 28, issue 5, article 8, pp. 1730-1737. 22 p. Available at: http://ir.lawnet.fordham.edu. (accessed: 14.01.2020)

\section{ГОСУДАРСТВЕННО-ЧАСТНОЕ ПАРТНЕРСТВО В СФЕРЕ ИННОВАЦИОННОЙ ДЕЯТЕЛЬНОСТИ: ЗАРУБЕЖНЫЙ ОПЫТ И ОТЕЧЕСТВЕННЫЕ РЕАЛИИ}

В статье определена важность государственно-частного партнерства для налаживания действенных механизмов развития инновационной деятельности и экономического роста страны. На основе обобщения нормативно-правовых и научных источников уточнено понятие государственно-частного партнерства в инновационной сфере и его преимущества для государства и частного (инновационного) бизнеса. Указаны направления взаимодействия государства и частного (инновачионного) бизнеса на разных стадиях развития: «посевной», стартапа, раннего роста, расширения. Изучен зарубежный опыт государственно-частного партнерства. Осуществлен анализ состояния государственно-частного партнерства в Украине, определены факторы, сдерживающие его развитие. Определены варианты государственно-частного партнерства в инновационной сфере Украины, возможности реализации и ожидаемые результаты.

Ключевые слова: государственно-частное партнерство, инновационная сфера, частный бизнес, инновационный бизнес, инновачионная деятельность, инвестиции, коммерциализация инновационной продукиии. 


\section{PUBLIC-PRIVATE PARTNERSHIP IN THE SPHERE OF INNOVATIONS: ABROAD EXPERIENCE AND DOMESTIC REALITIES}

The importance of public-private partnership for establishing effective mechanisms for development of innovative activity and economic growth of the country is defined in the article. The concept of public-private partnership is considered today in various fields: economics, legal, social, etc. The author of the scientific article clarifies the concept of public-private partnership in the sphere of innovations by summarizing the legal and scientific sources and advantages for the state and private (innovative) business. In such an interaction, private (innovative) business is able to implement important projects for the country and is protected from significant risks, and the state forms innovative infrastructure and provides its own competitiveness in the future. Areas of interaction between the state and private (innovative) business at different stages of development: "sowing", "startup", early grows and expansion, are indicated. Foreign experience of public-private partnership shows that each country independently chooses priority areas and depth of interaction between the state and business. The assessment of the state of public-private partnership in Ukraine showed that in our country a legal framework for investment has already been created, guarantees for investors, organizational and economic foundations for establishing partnership between the state and private business have been identified, but there are factors that impede this development. Among them: little experience in ensuring interaction between the state and business, lack of effective incentives for investors, economic instability and risks, poor development of innovative infrastructure, lack of qualified personnel, inconsistency of legislation. The options of public-private partnership in the innovation sphere of Ukraine, the possibilities of their realization and the expected results are outlined. Formation of a model of development of public-private partnership in the innovation sphere will allow to forming a national innovation system and competitive advantages for the country in future.

Key words: public-private partnership, innovation sphere, private (innovative) business, innovative business, innovative activity, investments, commercialization of innovative products. 